DOI: $10.22616 /$ REEP.2020.052

\title{
Career Guidance for First-Year Students in Work-Based Learning
}

\author{
Kristine Rutina ${ }^{1}$ Mg.ed.; Inita Soika ${ }^{2}$ Mg.paed. \\ Vocational Education Competence Centre "Riga Technical College", Latvia ${ }^{1}$ \\ Latvia University of Life Sciences and Technologies, Latvia ${ }^{2}$ \\ kristine.rutina@gmail.com ${ }^{1}$; inita.soika@llu.lv²
}

\begin{abstract}
The research focuses on the problem that first-year students of secondary vocational schools have an urgent need for informative, educational and counselling guidance, pointed on identifying their career needs and learning about the industry from the first day of studies. The aims of the study are firstly, to identify and evaluate the support needed for first-year learners to successfully integrate into work-based learning and develop their career management competences; secondly - to develop guidance program for first-year students and make an expert assessment of its effectiveness. The study was carried out by assessing the current situation in the field of career guidance for first-year students in vocational secondary education, as well as by interviewing first-year students, teachers, and employers involved in work-based learning. Evaluating their views and reflecting on the authors' personal experience has provided the basis for the development of a first-year career guidance program. The most significant findings indicate that by identifying first-year students' career needs and adjusting them to career guidance activities, they will develop their career management skills to better cope with the challenges and transition from education to work. Career guidance in work-based learning will be useful if all stakeholders - students, a group teacher, subject teachers, practice supervisors, career guidance professionals and employers - work together. The results of the study point to the importance of the impact of the education and work environment on the career development of first-year students. As a result, a career guidance program has been developed, the content of which will encourage firstyear students to understand themselves and the significance of their learning in their chosen profession.
\end{abstract}

Keywords: career guidance, first-year students, work-based learning, vocational education.

\section{Introduction}

The guidelines of European Union (Reform of Educational..., 2015; Seven Questions about..., 2018; Implementing a Holistic..., 2019; Guidance: Supporting Youth..., 2019) and Latvia (Par karjeras izglitīibas..., 2015; Darbibas programmas..., 2016) provides for the mandatory provision of career guidance for students in vocational secondary education able to develop and plan their careers and successfully enter the labour market. This reasoned indication relates to the following adverse trends. Firstly, the stereotype is that young people who choose to pursue secondary vocational education after leaving primary school have already made their career choices and are no longer in dire need of guidance. Secondly, the first-year students have to undergo a difficult period of adaptation to fit in new learning and living conditions. Therefore, they need support not only from families and group educators but also coordinated support from educators involved in organizing of work-based learning. This would help build confidence in students about the need to pursue a chosen profession or change if the wrong choice is made.

The relevance of the study was also determined by the European Union declaration on priorities in vocational education and training - promoting work-based learning, involving the social partners, businesses, industry association councils and vocational training providers (EU Policy in..., 2019; The Future of Education..., 2018). The authors' long-term professional experience in secondary vocational education suggests that first-year students lack accurate career information and specific career education activities to enhance their career management competence.

According to the self-evaluation data of the Vocational Education Competence Centre "Riga Technical College" (Pašvērtējuma ziņojums..., 2018), almost half - $49 \%$ - of first-year students fail to continue their studies for various reasons. This suggests that they lack self-cognitive skills that hinder both personal and career development, as well as the ability to study the labour market, plan their daily lives and make informed career choices. In addition, in work-based learning, students have been found to lack motivation to do simple tasks, to communicate and solve problems, and to lack a sense of responsibility. The mentioned problems hinder the students to acquire the profession in the work environment successfully. Therefore, one solution is to provide targeted educational and psychological guidance, whereby 
workplace-based tutors and educators interact with first-year students and help them adopt new learning and living conditions from the first day of study. Studies conducted in vocational secondary education by Dutch scientists (Kuijpers, Meijers, Gundy, 2011) has shown that as a result of dialogic career guidance activities, students have a better understanding of learning and work paths and choices, and are therefore more motivated to acquire a profession. One also has to agree with Danish scholar L. Hojdal (2019) that productive career guidance is when complex, multidimensional and individual, as well as contextual factors are taken into account as they influence people's perceptions and actions about their career choices.

The aim of the study is to justify the need for career guidance for first-year students in work-based learning and to develop and evaluate a career guidance program.

\section{Methodology}

The research included two questions: 1) What kind of career support is needed for first-year students to successfully initiate and continue learning in secondary vocational education? 2) In what ways does a career guidance program encourage first-year students to develop their career management skills to successfully integrate into work-based learning?

Methods of the research included a theoretical study, analysis of scientific literature, reflection of authors' personal experience, a survey of students and employers as well as data descriptive statistics and Friedman's test are used. The study involved 45 first-year students who have mastered the work-based learning.

The study includes the following stages: Stage 1 includes research, analysis and evaluation of scientific literature; Stage 2 includes a survey on career guidance for first-year students and employers in workbased learning; Stage 3 - developing a career guidance program based on the survey results; Stage 4 is carried out expert evaluation of career guidance program and their adjustment according to expert advice. The obtained results are analyzed for program approbation.

The survey included both open questions and questions to which answers were provided. The surveyed students were aged between 16 and 17 years. The survey was conducted in the second half of the school year when first-year students had already formed an opinion and gained first-hand experience of work-based learning. Employers whose companies provide work-based learning for first-year students are also surveyed.

The Career Guidance program for first-year students of vocational secondary education was developed at the Institute of Education and Home Economics, Latvia University of Life Sciences and Technologies within the Master study program Career Counsellor. The program was approbated at the Riga Technical College. The career guidance program for first-year students was evaluated by five competent experts and their ratings were subjected to statistical analysis using Friedman test. The experts were asked to evaluate the given criteria in the four-point scale: yes (4), rather yes than no (3), rather no than yes (2), no (1).

\section{Results and Discussion}

\section{Theoretical Framework for First-year Students Career Guidance in Work-Based Learning}

Nowadays, more and more young people, after leaving primary school, opt to continue their studies in secondary vocational education because of it an opportunity to enter the labour market faster and become self-sufficient. This is facilitated by the gradual introduction of a new form of vocational education and training - work-based learning - into secondary vocational education (OECD Skills Strategy..., 2019). Work-based learning is considered to be an important factor in career development and support because the acquisition of knowledge, skills, and competencies takes place according to the actual job requirements of the profession to be acquired (Procedures by which..., 2016; Work-Based Learning..., 2014; Katane, Katans, Īriste, 2016).

All life of young people and personality development are linked to preparation for adult life through secondary vocational education. It continues the young person's professional self-determination and readiness for independent professional activity, which helps to understand whether the profession has been chosen correctly and to consider different options of career development (Zeer, 2006; Elkonin, 2011). The development of a young person's value system is influenced by the peculiarities of educating in the family, as well as peculiarities of the cultural and socio-economic development of a certain society. The development of self-awareness is also influenced by the formation of worldview, which is related to the search for answers to existential questions of life. The young person's worldview also 
includes his/her subjective attitude towards work, people, the world of things and nature. D. Elkonin recognizes that guiding values and real opportunities influence young people's career choices. However, they may not be compatible with the necessary personality traits in the relevant profession group, which may sooner or later lead to dissatisfaction with the choices made. To prevent this, it is important for young people themselves to be aware of their career needs (Elkonin, 2011). Both the emergence of career choice issues, the efforts to match career choice with self-esteem, the awareness of the diversity of options and the formulation and testing of self-hypotheses, and the search for a teacher as a trusted supporter are all noteworthy features of career guidance for first-year students.

The development of career management competence is one of the aims of career guidance of students in secondary vocational education (Gravina, Lovšin, 2012). To make it happen, a series of flexible information, education, and counselling activities must be undertaken that are integrated into the educational process (Par karjeras izglîtîbas..., 2015), which can be implemented not only face-to-face but also through various online tools, such as communication and discussion on the Internet (Racene, Dislere, 2014). The acquired career management competence ensures the development of the student's self-knowledge and adequate assessment of one's abilities; research and evaluation of diverse labour market offerings; planning own career, setting goals, and making well-considered decisions to start meaningful activities, to realize them, and to stick to own choices (Soika, 2014; Hawkin, 1999). Also, decision-making ability is crucial in career choice and management processes, because properly weighted decisions provide maximum the best possible result, whatever the individual's professional field (Lifelong Guidance Policy..., 2012). First-year students can acquire career management competence with the help of teachers, parents, friends, employers, and colleagues. It can be developed by combining formal and non-formal education with one's experience. But not all students succeed. Therefore, there is a need for educational, informative and advisory activities whose content is capable of meeting first-year students' professional interests and career needs and motivating them to learn.

\section{Substantiation of the need for career guidance for first-year students}

Both practice and theory show that the main difficulties in career development at a young age are associated with inadequate self-knowledge and difficulties in decision-making (Greenhaus, Callanan, Godshalk, 2009). The authors agree with H.M. Knoff's recognition that young people's social competence and self-esteem is largely shaped by the accumulation of positive learning experiences and interpersonal relationships with peers. If young people integrate successfully into the social environment, they will easily learn not only to accept their new social roles but to be comfortable with themselves and able to accept themselves and others. The young person learns mutual responsibility and help; he/she develops a capacity for cooperation and trust; he/she is dominated by feelings of security and self-worth (Knoff, 2003). Communicating with others creates awareness of oneself, one's intentions and desires. For educators and other stakeholders to perceive students as equals and to understand their needs in work-based learning, it is necessary to build and maintain peer-to-peer collaboration that enables each of them to reflect upon and weight out on their new experiences (Soika, 2015; Soika, 2017).

It is important for first-year students to adapt to the new learning and living environment by starting their studies at a vocational secondary school. According to the authors' experience, the greatest difficulties encountered at the start of the school year by the first-year students are the differences in the organization of the learning process compared to the elementary school, such as the layout of the classes, the monthly certification, and the pace. This requires not only timely and appropriate support from career professionals but also the support of vocational teachers and general education teachers because they help to understand and adapt to new learning conditions. This is also noted by the vast majority of first-year students surveyed - out of 45 students 36 - who wish to receive career development support specifically for their profession as they go to study with their employer. This would ensure a faster and more successful assessment of the chosen profession and facilitate the harmonious development of the students' personality. Until recently, the main supporters were group teachers (Kuijpers, Meijers, 2017; Soika, 2014).

The authors' observations suggest that very broad and general career guidance is available so far for the first-year students, but that there is a lack of specific activities that students might acquire the career management skills needed to successfully adapt and start learning at workplace. For example, to evaluate own personality and own learning style; to explore a profession in connection with the subjects; to study 
the labour market requirements of the sector; to develop an action plan for getting to know one's work environment in the company. Therefore, career counsellors should more often inform teachers and students about the possibility of engaging in integrated career guidance activities in the learning process that educates them in career management skills, and of using individual and group counselling services.

The collected survey data show that:

- the first-year students would be more successful in adapting if they received support from the first days of schooling. This would provide more detailed information and a clearer understanding of the profession and industry being studied. It is noted by 32 of the surveyed 45 students.

- sixteen respondents feel that they have lacked support to acquire general education subjects and understand their importance in their chosen profession.

- two-thirds, or 30 first-year students, recognize the need for support in missing knowledge in order to succeed in learning.

- twenty respondents need support from the company' supervisor.

- in turn, twenty-eight out of 45 respondents would like to receive support from teachers of professional subjects.

- twenty-three out of 45 respondents admit that they need individual career counselling to facilitate their learning in work-based learning. This shows that the students are aware of the problems associated with learning and career development and an inability to deal with them themselves, so their solution is necessary for the advice of career counsellors.

- only four respondents indicated that the received guidance is sufficient.

- twenty percent or 9 first-year students surveyed lack of family support. This can be explained by the fact that students from all over Latvia study at Riga Technical College, so there are students who stay in a dormitory.

Also, first-year students recognize that potential employers and internships want them to be responsible, motivated, disciplined and communicative. This coincides with the employer's point of view. Their most demanded competences from students are professional motivation, ability to quickly absorb new information, purposeful drive for results, communication skills, and ability to work independently, ability to meet deadlines, organizational skills, and language skills. This demonstrates that first-year students know what skills and character traits they need to develop to be successful in their chosen professional field.

\section{Characteristic of First-Year Career Guidance Program}

A career guidance program for first-year students in work-based learning was developed to address the challenges described above. It has been developed based on the career guidance stages of vocational secondary education (Karjeras izglîtība profesionālās..., 2006). The thematic planning of the program is based on the learning process of the first-year students and the provision of the necessary career support. The number of classes in each topic depends on the needs of the group and students. Career guidance activities are integrated into the learning process and in extracurricular activities. School career counsellors and teachers of theoretical and practical subjects, and work-based supervisors are involved in implementing the content of the guidance program. The program is based on the principles of the U. Bronfenbrenner's Ecological Approach to Education (Bronfenbrenner, 1979) where student development is viewed as a progressive process of interaction between the environment and the student himself. The aim of the career guidance program is to facilitate the integration of first-year students into work-based learning and to develop their career management competence. The program was developed by the authors of this article (Rūtina, 2019). Career guidance activities are carried out from the first day of studies and will continue throughout the study year. Topics, objectives and results are shown in Table 1 . The topics of the career guidance activities are described above, indicating the need for learning and emphasizing the benefits of first-year students in their career development. Recommended methods and forms of learning organization are also indicated, as well as those responsible persons for organizing the acquirement of the topic.

Mastering the first topic, 'Social Adaptation in New Conditions', is needed to enable first-year students to adapt to the new learning environment. The first-year students must lay a secure foundation for their educational environment during the adaptation period. This can be successfully done by providing timely quality psychological, educational and career support. Successful adaptation in a group contributes to students' learning and integration into the collective, getting to know each other and form 
close cooperative ties in all learning time, which later may develop as a network that promotes the professional learning and further career development. Methods and forms of a learning organization: presentations, dating games, group work, questionnaires, tests, discussions. Responsible persons and implementers: group teacher, school career counsellor, subject teachers.

Table 1

Thematic planning of first-year students' career guidance program for work-based learning

\begin{tabular}{|c|c|c|}
\hline Topic & The aim & $\begin{array}{l}\text { Achievable result and development of career management } \\
\text { skills (CMS) }\end{array}$ \\
\hline $\begin{array}{l}\text { 1. Social } \\
\text { adaptation in } \\
\text { the new } \\
\text { environment }\end{array}$ & $\begin{array}{l}\text { To develop an } \\
\text { experience of mutual } \\
\text { cooperation in new } \\
\text { learning and living } \\
\text { conditions }\end{array}$ & $\begin{array}{l}\text { 1) Able to understand changes and adapt to new circumstances. } \\
\text { 2) Knows what guidance is available in an educational } \\
\text { institution. } \\
\text { CMS: self-knowledge, self-esteem and self-development }\end{array}$ \\
\hline $\begin{array}{l}\text { 2. Get to know } \\
\text { the chosen } \\
\text { profession }\end{array}$ & $\begin{array}{l}\text { To understand the } \\
\text { opportunities and } \\
\text { requirements of the } \\
\text { industry's market }\end{array}$ & $\begin{array}{l}\text { Knows the labour market requirements of the industry in the } \\
\text { chosen profession and understands their importance. } \\
\text { CMS - an exploration of the profession }\end{array}$ \\
\hline $\begin{array}{l}\text { 3. } \\
\text { Understanding } \\
\text { of values }\end{array}$ & $\begin{array}{l}\text { To promote a deeper } \\
\text { self-knowledge }\end{array}$ & $\begin{array}{l}\text { 1) Is able to define his / her values and understand how they } \\
\text { can be useful in the profession. } \\
\text { 2) Knows that values need improvement } \\
\text { CMS: self-knowledge, self-esteem, self-development, and } \\
\text { analysis of the results }\end{array}$ \\
\hline $\begin{array}{l}\text { 4. Defining of } \\
\text { learning styles }\end{array}$ & $\begin{array}{l}\text { To be able to evaluate } \\
\text { one's abilities and } \\
\text { created opportunities } \\
\text { in the learning process }\end{array}$ & $\begin{array}{l}\text { Knows learning styles and understands own learning style } \\
\text { CMS: self-knowledge, self-esteem, self-development, and } \\
\text { analysis of the results }\end{array}$ \\
\hline $\begin{array}{l}\text { My strengths } \\
\text { and character } \\
\text { traits that are } \\
\text { useful for my } \\
\text { profession }\end{array}$ & $\begin{array}{l}\text { To be aware of own } \\
\text { strengths and } \\
\text { weaknesses }\end{array}$ & $\begin{array}{l}\text { 1) Able to discover and analyse own strengths and weaknesses. } \\
\text { 2) Knows strategies for promoting self-esteem. } \\
\text { CMS: self-knowledge, self-esteem, self-development, and } \\
\text { decision-making }\end{array}$ \\
\hline $\begin{array}{l}\text { 6. Formation of } \\
\text { Digital Portfolio }\end{array}$ & $\begin{array}{l}\text { To create and use a } \\
\text { digital portfolio that } \\
\text { will help the career } \\
\text { decision-making }\end{array}$ & $\begin{array}{l}\text { Able to create and enrich a digital career portfolio using the } \\
\text { varied resources of ICT. } \\
\text { CMS: selection, analysis, compilation and visualization of } \\
\text { information; self-knowledge }\end{array}$ \\
\hline $\begin{array}{l}\text { 7. Role of study } \\
\text { subjects in the } \\
\text { acquisition of a } \\
\text { profession }\end{array}$ & $\begin{array}{l}\text { To understand the } \\
\text { importance of the } \\
\text { study subjects in the } \\
\text { acquirement of } \\
\text { profession }\end{array}$ & $\begin{array}{l}\text { Able to see the connection between the study subject and the } \\
\text { profession. } \\
\text { CMS: occupational research in the field of study subjects }\end{array}$ \\
\hline $\begin{array}{l}\text { 8. Introductory } \\
\text { day at the } \\
\text { company }\end{array}$ & $\begin{array}{l}\text { To give a concept } \\
\text { about the specifics of } \\
\text { work in the industry }\end{array}$ & $\begin{array}{l}\text { 1) Have a picture of the company where the training will take } \\
\text { place. } \\
\text { 2) Is aware of the tasks and requirements set out in the } \\
\text { individual plan. } \\
\text { CMS: research into the world of work; decision-making; } \\
\text { developing an action plan. }\end{array}$ \\
\hline $\begin{array}{l}\text { 9. Development } \\
\text { of social skills } \\
\text { for work-based } \\
\text { learning }\end{array}$ & $\begin{array}{l}\text { To promote the } \\
\text { development of social } \\
\text { skills and the ability to } \\
\text { use them in the work } \\
\text { environment. }\end{array}$ & $\begin{array}{l}\text { 1) Able to present oneself, make contacts and collaborate with } \\
\text { colleagues in the work environment. } \\
\text { 2) Is able to solve work-related problems. } \\
\text { 3) Is able to improve the skills necessary to carry out work in } \\
\text { the chosen profession. } \\
\text { CMS: self-knowledge, self-evaluation; decision-making, } \\
\text { development of competencies. }\end{array}$ \\
\hline $\begin{array}{l}\text { 10. How to deal } \\
\text { with doubts and } \\
\text { uncertainty? }\end{array}$ & $\begin{array}{l}\text { To be able to deal with } \\
\text { doubts and make the } \\
\text { right decision. }\end{array}$ & $\begin{array}{l}\text { 1) Know where to get career guidance. } \\
\text { 2) Able to make informed decisions. } \\
\text { CMS: self-knowledge; study of labour market conditions in the } \\
\text { sector; decision-making. }\end{array}$ \\
\hline
\end{tabular}


The second topic, 'Get to Know Your Profession', allows first-year students to get to know the profession in more detail and get more accurate information about the job market in their chosen profession and the latest industry news. This usually takes the form of work-based learning, supervised by the manager from the school, and meetings with graduates and employers. Methods and forms of learning organization: presentations, narration, review, discussions, questions and answers. Responsible persons and implementers: school career counsellor, supervisors of work-based learning in the educational institution and representatives of employers.

The third topic, 'Understanding of Values', should be acquired by first-year students to enhance their understanding of the educational value, knowledge, skills, abilities, attitudes, and characteristics that they need to acquire and use in order to be successful in their chosen profession. Methods and forms of the learning organization: game of values, discussion and group work. Responsible persons and implementers: group teacher and school career counsellor.

The fourth topic, 'Defining of Learning Styles', is a topical issue because students usually lack the skills to learn in new settings. During the lesson, students can learn about their dominant learning style and how it affects their learning and working in the group, as well as their relationships with others. Methods and forms of the learning organization: a test of learning styles, discussions, brainstorming. Responsible persons and implementers: group teacher and school career counsellor.

During the fifth topic, 'My Strengths and Character Traits', students learn to evaluate their strengths and weaknesses and to identify which traits should be further developed in their chosen profession. Students will be able to motivate themselves if they know their strengths and weaknesses. Methods and forms of the learning organization: SWOT analysis, individual work, discussions, role-playing games. Responsible persons and implementers: group teacher and school career counsellor.

Acquiring the sixth topic 'The development of Digital Portfolio', will enable the young person to create their own life story using information and communication technology tools such as the YouRock tool. It offers students the opportunity to show their various working skills, which are often "hidden" in their daily activities, and to name them in the language of their employers. Young people have the opportunity to create full-fledged, dynamic profiles on the YouRock website that give employers insight into their skills (YouRock, 2019). The development of portfolio is the individual work of each student. Responsible persons and implementers: group teacher, school career counsellor and computer science teacher.

Acquisition of the seventh topic 'Role of study subjects in the acquisition of a profession' develops students' understanding of why a subject should be learned and how it will benefit them. It helps firstyear students identify what skills they can develop and where they can be used to further their careers. Methods and forms of the learning organization: mind map on the importance of subjects in the chosen profession, visualization, situational games, brainstorming, discussions. Responsible persons and implementers: subject teachers.

The aim of the eighth topic, 'Introductory Day at the Company', is to introduce first-year students to the real world of work in the company so that they feel safe from the first day of studies. This is the student's first meeting with his / her learning manager at the company. The student is introduced to the individual plan for mastering the relevant work tasks, company' employees and work discipline. Methods and forms of a learning organization: study tour, presentations, and discussions. Responsible persons and implementers: management of companies and supervisors of the work-based learning in educational institution and companies.

The ninth topic, 'Developing Social Skills for Work-Based Learning', is needed to help students learn to collaborate with colleagues in the work environment, to engage in collective and independent problem-solving, and to learn how to achieve and how to motivate them self to reach them. Methods and forms of the learning organization: business games, group work, brainstorming, discussions, and mapping. Responsible persons and implementers: group teacher, school career counsellor and supervisors of the work-based learning in educational institutions and companies.

Acquisition of the tenth topic, 'How to Deal with Doubts' provides individual career counselling to help students make informed career choices about their chosen profession and career development. Responsible persons and implementers: school career counsellors and career counsellors. 


\section{Expert Evaluation of the of first-year students' Career Guidance program}

The authors wanted to find out whether pursuing a career guidance program would enhance first-year students' career management skills so that they could successfully integrate into work-based learning. Experts were therefore asked to evaluate it. Five experts with experience in vocational education (A, B, $\mathrm{D})$, career guidance $(\mathrm{B}, \mathrm{C}, \mathrm{D}, \mathrm{E})$ and work-based learning $(\mathrm{D}, \mathrm{E})$ were involved in the evaluation of the career guidance program. Questionnaires were sent to the experts to assess the usefulness of the career guidance program for the adaptation of first-year students to work-based learning. The maximum possible score is 20 points per question.

Analysing expert evaluations, it should be noted that the first question of the experts' questionnaire "Does the theme of the classes facilitates the adaptation of the first-year students to the new learning conditions?", has the lowest total score, that is 18 of all questions. Two experts responded to this question with "rather than no". Expert $\mathrm{C}$ recommends attracting mentors from senior courses to help first-year students become more comfortable with the new learning and living environment.

To the second question, "Do the goals set for the classes match the results to be achieved?" all experts have given the highest rating - 4 points (yes), with the exception of experts $\mathrm{C}$. This expert answered "Rather yes, than not", pointing out that research of sector-specific of the labour market is equally important in identifying its strengths and character traits (Topic 5) and dealing with their doubts and uncertainties (Topic 10). This would facilitate the process of individual consultations. The evaluation of both topics is three points. The other experts gave the highest rating - four points.

To the third question, "Are the proposed methods sufficient to achieve the goal?" expert C answered, "Rather yes than no". Expert C recommends using visualization techniques, such as creating a company portfolio as a poster. The other four experts have given the highest rating - 4 points.

Four experts gave the highest rating to the fourth question "Are the topics and number of lessons sufficient to support first-year students in work-based learning?" However, expert E has rated it with three points, stating that lessons need to be more practiced in the corporate work environment for firstyear students to better understand which knowledge and skills are most needed to successfully integrate into work-based learning.

Four experts also gave the highest evaluation to the fifth question "Is the program generally acceptable and suitable for first-year learners in work-based learning?". However, expert $C$ rated it with three points, stating that an annual survey should be conducted to understand the career needs of first-year students. This would give the opportunity to understand which career guidance activities are implemented in solving students' career issues.

Expert A has welcomed the lessons learned and recommends that this type of career guidance program be extended to third-year and fourth-year students to better prepare them for the transition from education to the labour market. Expert B is welcomed that it is designed for individual career counselling because they generally lack both time and professional competence of career specialists to carry out. In turn, an expert D notes that the topics promotes modular training system for secondary vocational education, where the module "Social and civic competences" offers similar topics. The expert evaluation's data were processed using the SPSS program and Friedman test (Table 2). This is a nonparametric test for several paired groups. The test is used for interval and ordinal scale data.

Table 2

\section{Friedman test statistics}

\begin{tabular}{lr}
\hline \multicolumn{2}{c}{ Test statistics } \\
\hline Number (N) & 5 \\
Chi-Square & 11.64 \\
Degree of freedom (Df) & 4 \\
p - value (Asymp.Sig.) & 0.20 \\
\hline
\end{tabular}

The $p$-value $=0.20>\alpha=0.05$, acquired in the result of secondary processing of the data allows concluding that there were no significant differences in ratings among the experts. Overall, the experts have highly evaluated the career guidance program for first-year students, which indicate that it is appropriate for the intended purpose. 


\section{Conclusions}

The results of the study show that first-year students of secondary vocational education needs career guidance that facilitates their adaptation to new learning and living conditions - work-based learning and facilitates the development of the necessary career management skills:

- to promote deeper self-knowledge and self-exploration;

- to understand themselves as future professional;

- to understand the industry's market opportunities and requirements;

- to get to know profession in a real working environment;

- to develop the social skills needed for work-based learning;

- to be able to cope with the doubts and make the right decisions;

- to understand the role of learning in the profession and in career development;

- to obtain a diverse and high-quality learning experience in a real work environment.

This kind of career guidance provides more flexibility in the implementation of vocational education programs by acquiring theory in an educational institution and practical skills and competences - in an enterprise.

The content of the career guidance program underlines the need to engage and collaborate in its implementation with the teaching staff of the vocational educational establishment - group teachers, career guidance specialists (career counsellors and school career counsellors) and subject teachers, as well as with representatives of employers and the managers of work-based learning.

First-year students' career guidance requires the use of a variety of methodological techniques and forms of learning that develop communication and collaboration skills, self-presentation skills, and research and critical thinking skills to make the right decisions.

There is no significant difference in experts' evaluations for first-year students in career guidance. This indicates that career guidance program facilitates the integration of first-year students into work-based learning and enhances their career management competence.

\section{Bibliography}

1. Bronfenbrenner U. (1979). The Ecology of Human Development: experiments by nature and design. Cambridge: Harvard University Press.

2. Darbības programmas "Izaugsme un nodarbinātība" 8.3.5. specifiskā atbalsta mērksa "Uzlabot pieeju karjeras atbalstam izglītojamajiem vispārējās un profesionālās izglītības iestādēs" ìstenošanas noteikumi [Operational Program "Growth and Employment" 8.3.5. Implementing Provisions for the Specific Support Objective "Improving Access to Guidance for Learners in Education and Training"]. (2016). Rịga: MK noteikumi Nr. 359. no 07.06.2016. Retrieved from https://likumi.lv/ta/id/283023 (in Latvian)

3. Elkonin D.B. (2011). Detskaja psihologija [Child psychology]. Moskva: Izdatel'skij centr „Akademija”. (in Russian)

4. EU Policy in the Field of Vocational Education and Training. (2019). European Commission. Retrieved from https://ec.europa.eu/education/policies/eu-policy-in-the-field-of-vocational-education-and-training-vet_en

5. Gravina D., Lovšn M. (2012). Career Management Skills: Factors in Implementing Policy Successfully. ELGPN Concept note No. 3, Jyvaskyla: Finnish Institute for Educational Research. Retrieved from http://www.elgpn.eu/publications/browse-by-language/english/Gravina_and_Lovsin_cms_concept_note_web.pdf/

6. Greenhaus J.H., Callanan G.A., Godshalk V.M. (2009). Career Management (4 ${ }^{\text {th }}$ ed.). Thousand Oaks: SAGE Publications, Inc.

7. Guidance: Supporting Youth to Manage Their Careers. (2019). CEDEFOP. Retrieved from https://www.cedefop.europa.eu/et/printpdf/toolkits/vet-toolkit-tackling-early-leaving/interventionapproaches/guidance-supporting-youth-manage-their-careers

8. Hawkin P. (1999). The Art of Building Windmills. Career Tactics for the 21st Century. Liverpool: Graduate into Employment Unit.

9. Hojdal L. (2019). Career Counselling. Themes and Methods. Copenhagen: Libert Hojdal.

10. Implementing a Holistic Approach to Lifelong Learning: Community Lifelong Learning Centres as a Gateway to Multidisciplinary Support Teams. (2019). Lifelong Learning Platform, CEDEFOP. Retrieved from https://www.cedefop.europa.eu/files/2226_en.pdf

11. Karjeras izglītīiba profesionālās vidējās izglìtības iestādēs. Skolotāja rokasgrāmata [Career education in vocational secondary education institutions. Teacher's Guide]. (2006). Rīga: 
Profesionālās izglìtības attīstības aǵentūra. Retrieved from http://viaa.gov.lv/files/news/722/prof _karjeras_izgl_rokasgr_skolot.pdf (in Latvian)

12. Katane I., Katans E., Iriste S. (2016). Workplace-Based Learning in Theory and Dual System of Professional Education in Practice. In V. Lubkina, R. Bubnys (Eds.), The Proceedings of the International Scientific Conference Society. Integration. Education, Rezekne: RTA, 125-136. doi: 10.17770/sie2016vol1.1506

13. Knoff H.M. (Ed.). (2003). The Assessment of Child and Adolescent Personality. London: The Guilford Press.

14. Kuijpers M., Meijers F. (2017). Professionalising Teachers in Career Dialogue: an Effect Study. British Journal of Guidance and Counselling, 45(1), 83-96. doi: 10.1080/03069885.2015.1121203

15. Kuijpers M., Meijers F., Gundy C. (2011). The Relationship Between Learning Environment and Career Competencies of Students in Vocational Education. Journal of Vocational Behavior, 78(1), 21-30. doi: $10.1016 / j . j v b .2010 .05 .005$

16. Lifelong Guidance Policy Development: A European Resource Kit. (2012). The European Lifelong Guidance Policy Network. University of Jyvaskyla. Jyvaskyla: Saarijärven Offset Oy. Retrieved from http://www.elgpn.eu/publications/browse-by-language/english/ELGPN_resource_kit_2011-12_web.pdf

17. OECD Skills Strategy Latvia: Assessment and Recommendations. OECD Skills Studies. (2019). Paris: OECD Publishing. doi: 10.1787/74fe3bf8-en

18. Par karjeras izglìtības ìstenošanas plānu valsts un pašvaldību vispārējās un profesionālās izglìtības iestādēs 2015.-2020. gadam [About the Career Education Implementation Plan for State and Municipal General and Vocational Education Institutions for 2015-2020]. (2015). MK rīkojums Nr. 821 no 30.12. 2015. Rīga: LR MK. Retrieved from https:/likumi.lv/ta/id/278999 (in Latvian)

19. Pašvērtējuma zinojums izglìtibas programmu „Energétika un elektrotehnika. Elektronika. Telekomunikācijas. Programmēšana. Datorsistēmas, datubāzes un datortīkli. Autotransports. Metālapstrāade. Kokizstrādājumu izgatavošana" akreditācijai [Self-assessment Statement for the Educational Programs "Energy and Electrical Engineering. Electronics. Telecommunications. Programming. Computer Systems, Databases and Computer Networks. Road transport. Metalworking. Wood Production" Accreditation]. (2018). Rīga: Profesionālās izglititibas kompetences centrs "Rīgas tehniskā koledža". Retrieved from http://www.rtk.lv/?fails=1519905092.pdf (in Latvian)

20. Procedures by which Work-based Learning is Organised and Implemented. (2016). Rìga: Republic of Latvia, Cabinet of Ministers, Regulation No. 484. Retrieved from https://likumi.lv/ta/en/en/id/283680

21. Rācene A., Dislere V. (2014). Internet Tools as a Kind of Career E-Guidance. In V. Dislere (Ed.), The Proceedings of the International Scientific Conference Rural Environment. Education. Personality (REEP), 7. Jelgava: LLU, 200-207. Retrieved from https://llufb.llu.lv/conference/REEP/2014/Latvia-UnivAgricult-REEP-2014proceedings-200-207.pdf

22. Reform of Educational Systems: European Policies for Lifelong Guidance to Fight Early School Leaving and Unemployment. (2015). European Parliament. doi: 10.2861/608356

23. Rūtina K. (2019). Karjeras attīstības atbalsts 1.kursa audzēknniem darba vidē balstîtās māāîāās. [Career Guidance for First-Year Students in Work-Based Learning]. (Master Thesis, Latvia University of Life Sciences and Technologies, Jelgava). (in Latvian)

24. Seven Questions about Apprenticeships. Answers from International Experience. (2018). In OECD Reviews of Vocational Education and Training. doi: 10.1787/9789264306486-en

25. Soika I. (2014). Development of Student's Career Management Competency in Vocational Secondary Schools. In A. Aboltins (Ed.), The Proceedings of the International Scientific Conference Engineering for Rural Development, 13. Jelgava: LLU, 511-516. Retrieved from http://www.tf.llu.lv/conference/proceedings2014/Papers/87_Soika_I.pdf

26. Soika I. (2015). Entity of Dialogue in Career Guidance of Secondary Vocational Schools. In V. Dislere (Ed.), The Proceedings of the International Scientific Conference Rural Environment. Education. Personality (REEP), 8. Jelgava: LLU, 338-346. Retrieved from https://llufb.llu.lv/conference/REEP/2015/Latvia-Univ-Agricult-REEP-2015proceedings-338-346.pdf

27. Soika I. (2017). Evolution of Dialogue for Students' Career Guidance in Secondary Vocational Education. In V. Dislere (Ed.), The Proceedings of the International Scientific Conference Rural Environment. Education. Personality (REEP), 10. Jelgava: LLU, 481-488. Retrieved from https://llufb.llu.lv/conference/REEP/2017/Latvia-Univ-Agricult-REEP-2017_proceedings-481-488.pdf

28. The Future of Education and Skills. Education 2030. (2018). Paris: OECD Publishing. Retrieved from https://www.oecd.org/education/2030/E2030\%20Position\%20Paper\%20(05.04.2018).pdf

29. Work-Based Learning. A Handbook for Policy Makers and Social Partners in ETF Partner Countries. (2014). Turin: European Training Foundation. Retrieved from http://www.etf.europa.eu/sites/default/files/ m/8EFD210012D6B04EC1257CE60042AB7E_Work-based\%20learning_Handbook.pdf

30. YouRock. (2019). Retrieved from https://yourock.jobs/en

31. Zeer E.F. (2006). Psihologija profesiji [Occupational Psychology]. Moskva: Akademicheskij project, Fond „Mir”. (in Russian) 